\title{
Gastroliths in an ornithopod dinosaur
}

Ignacio A. Cerda

Acta Palaeontologica Polonica 53 (2), 2008: 351-355 doi:http://dx.doi.org/10.4202/app.2008.0213

Gastroliths (stomach stones) are known from many extant and extinct vertebrates, including dinosaurs. Reported here is the first unambiguous record of gastroliths in an ornithopod dinosaur. Clusters of small stones found in the abdominal region of three articulated skeletons of Gasparinisaura cincosaltensis were identified as gastroliths on the basis of taphonomic and sedimentologic evidence. The large number of stones found in each individual, their size, and the fact that Gasparinisaura cincosaltensis was herbivorous, all suggest that they were ingested as a result of lithophagy rather than accidental swallowing.

Ignacio A. Cerda [nachocerda6@yahoo.com.ar], CONICET-INIBIOMA-Museo de Geología y Paleontología, Universidad Nacional del Comahue, Buenos Aires 1400, 8300 Neuquén, Argentina.

This is an open-access article distributed under the terms of the Creative Commons Attribution License (for details please see creativecommons.org), which permits unrestricted use, distribution, and reproduction in any medium, provided the original author and source are credited. 